\title{
ANALISIS PENGARUH RASIO KINERJA KEUANGAN TERHADAP HARGA SAHAM PT BANK MANDIRI PERSERO PERIODE 2014 - 2019
}

\section{KETUT KUSUMA WIJAYA}

\author{
Program Studi Manajemen K. Mataram UNMAS Denpasar
}

ketutkusumawijaya78@gmail.com

\begin{abstract}
ABSTRAK
Harga saham terjadi sesuai dengan permintaan dan penawaran pasar. Permintaan saham dipengaruhi oleh ekspektasi investor terhadap perusahaan penerbit saham. Semakin baik kinerja keuangan suatu perusahaan, akan membuat ekspektasi investor semakin tinggi. Hal ini mengakibatkan saham tersebut akan semakin diminati dan harga saham tersebut akan semakin tinggi. Sebaliknya jika kinerja keuangan suatu perusahaan tidak baik, maka ekspektasi investor akan rendah, sehingga investor tidak berminat berinvestasi pada saham tersebut. Hal ini membuat harga saham turun. Kinerja keuangan perusahaan dapat dilakukan dengan menganalisis laporan keuangan. Penelitian ini bertujuan untuk mengetahui pengaruh rasio kinerja keuangan terhadap harga saham. Alat analisis yang digunakan yaitu regresi linear berganda dan pengujian hipotesis dilakukan dengan uji parsial (uji-T) dan uji simultan (Uji-F) serta uji koefisien standardized.

Berdasarkan hasil penelitian bahwa secara simultan variabel rasio keuangan tidak berpengaruh secara siginifikan terhadap harga saham. Sedangkan secara parsial hanya variabel NPM yang mempengaruhi harga saham. Sedangkan variabel kinerja keuangan (CAR, ROA dan LDR) tidak mempengaruhi harga saham. Untuk nilai adjusted $\mathrm{R}^{2}$ sebesar $99,80 \%$ artinya bahwa nilai ini berarti variasi variabel independen yang dapat menjelaskan variabel dependen sebesar $99,80 \%$ dan sisanya $2 \%$ variasi variabel lain yang tidak dijelaskan dalam model.
\end{abstract}

Kata kunci : Rasio Kinerja Keuangan dan Harga Saham

\section{ABSTRACT}

Share prices occur according to market supply and demand. Demand for shares is influenced by investors' expectations of the issuing company. The better the financial performance of a company, the higher investor expectations will be. This results in the shares becoming increasingly attractive and the share price will be higher. Conversely, if a company's financial performance is not good, investors' expectations will be low, so investors are not interested in investing in these shares. This causes the stock price to fall. The company's financial performance can be done by analyzing financial reports. This study aims to determine the effect of financial performance ratios on stock prices. The analytical tool used is multiple linear regression and hypothesis testing is done by partial test (T-test) and simultaneous test (F-test) and standardized coefficient test.

Based on the research results that simultaneously the financial ratio variable does not have a significant effect on stock prices. Meanwhile, only partially the NPM variable affects stock prices. Meanwhile, the financial performance variables $(C A R, R O A$, and LDR) do not affect stock prices. For the adjusted $R^{2}$ value of $99.80 \%$, it means that this value means that the variation of the independent variable which can explain the dependent variable is $99.80 \%$ and the remaining $2 \%$ is the variation of other variables that are not explained in the model.

Keywords: Financial Performance Ratio and Stock Price

\section{PENDAHULUAN}

Pasar modal sebagai salah satu sumber pembiayaan modal perusahaan memiliki karakteristik yang berbeda dari alternatif sumber pembiayaan lain misalnya sumber pembiayaan dari bank. Perusahaan yang terdaftar di pasar modal hanya akan membayar dividen kepada pemilik modal yang besarnya tergantung dari 
laba perusahaan. Sedangkan alternatif pembiayaan dari bank, perusahaan harus menyediakan dana yang jumlahnya tetap untuk membayar bunga dan pokok pinjaman kepada pemilik modal.

Setiap investor atau calon investor memiliki motif utama dalam berinvestasi yakni memperoleh keuntungan dari dana yang ditanamkan. Keuntungan dari berinvestasi dalam bentuk saham adalah capital gain dan dividen. Dalam melakukan investasi dalam bentuk saham, penting bagi para investor mengetahui kinerja keuangan perusahaan go public di Indonesia dan pengaruhnya terhadap harga sahamnya. Hal ini dilakukan agar para investor mendapatkan pengetahuan dan keyakinan terhadap kemampuan perusahaan untuk terus tumbuh dan berkembang pada masa yang akan datang.

Harga saham terjadi sesuai dengan permintaan dan penawaran pasar. Permintaan saham dipengaruhi oleh ekspektasi investor terhadap perusahaan penerbit saham. Semakin baik kinerja keuangan suatu perusahaan, akan membuat ekspektasi investor semakin tinggi. Hal ini mengakibatkan saham tersebut akan semakin diminati dan harga saham tersebut akan semakin tinggi. Sebaliknya jika kinerja keuangan suatu perusahaan tidak baik, maka ekspektasi investor akan rendah, sehingga investor tidak berminat berinvestasi pada saham tersebut. Hal ini membuat harga saham turun.

Kinerja keuangan perusahaan dapat dilakukan dengan menganalisis laporan keuangan. Salah satu bentuk analisis laporan keuangan adalah dengan menganalisis rasio-rasio keuangan. Untuk menilai suatu kinerja bank digunakan lima aspek penilaian yaitu CAMEL yaitu Capital (Modal), Asset (Aktiva), Management (Manajemen), Earning (Rentabilitas), Liquidity (Likuiditas), dan Sensitivity To Market Risk (Sensitivitas Terhadap Resiko Pasar) yang telah ditetapkan dalam Surat Keputusan Direksi Bank Indonesia Nomor 30/12/KEP/DIR, Surat Edaran Bank Indonesia No. 30/3/UPPB tanggal 30 April 1997 dan Surat Edaran Bank Indonesia No.6/ 23./DPNP tanggal 31 Mei 2004 yaitu tentang Tata Cara Penilaian Tingkat Kesehatan Bank Umum (CAMEL Rating).

Bank Mandiri sebagai salah satu perusahaan perbankan yang terdaftar di Bursa Efek Indonesia merupakan emiten dengan kinerja yang sangat baik. Dengan harga saham per lembar posisi akhir triwulan IV 2019 sebesar Rp.7.675 dengan volume kapitalisasi pasar sebesar 2,6 juta lembar senilai Rp.358,17 trilyun. Bahkan emiten dengan kode BMRI merupakan salah satu emiten yang termasuk dalam kelompok emiten dengan kode LQ 45. Kode ini merupakan emiten terbaik dengan volume transaksi dan kapitalisasi pasar tertinggi selama 12 bulan terakhir dan merupakan emiten dengan kinerja keuangan terbaik.

Rimi Gusliana Mais (2004) tentang pengaruh rasio-rasio keuangan utama perusahaan terhadap harga saham perusahaan yang terdaftar di Jakarta Islamic Index Tahun 2004. Hasil penelitian menunjukkan bahwa saham-saham yang tergabung dalam Jakarta Islamic Index harga sahamnya dipengaruhi signifikan secara bersama-sama oleh rasio-rasio keuangan utamanya yaitu variabel Net profit margin, Debt to equity ratio, Earning Per Share, Return on assets dan Return on equity.

Sedangkan Noor dan Rini (2005), "Pengaruh Likuiditas, Solvabilitas, ROI dan EPS terhadap harga saham pada perusahaan Food and Baverage yang listing di Bursa Efek Surabaya periode 2002 dan 2003". Perusahaan yang digunakan dalam penelitian ini sebanyak 11 perusahaan dengan menggunakan analisis regresi linier berganda. Hasil penelitian menyatakan bahwa Likuiditas, Solvabilitas, dan ROI tidak berpengaruh secara signifikan secara parsial terhadap harga saham. Sedangkan EPS menunjukkan pengaruh positif terhadap harga saham.

Berbagai definisi bank telah dikemukakan oleh berbagai ahli. Berikut ini beberapa pengertian bank antara lain :

1. Bank adalah suatu badan usaha yang tugas utamanya sebagai lembaga perantara keuangan (financial intermediaries) yang menyalurkan dana dari pihak yang berkelebihan (idle fund atau surplus unit) kepada pihak yang membutuhkan dana atau kekurangan dana (deficit unit) pada waktu yang ditentukan" (Dendawijaya, 2000:25)

2. Bank adalah badan usaha yang utamanya menciptakan kredit" (Suyatno, $1996: 1$ ).

3. Bank adalah suatu jenis lembaga keuangan yang melaksanakan berbagai jasa, seperti memberikan pinjaman, mengedarkan mata uang, pengawasan terhadap mata uang, bertindak sebagai tempat penyimpanan benda-benda berharga, membiayai perusahaan-perusahaan dan lain-lain (Abdurrachman, Ensiklopedia Ekonomi Keuangan dan Perdagangan)

Pengertian bank menurut PSAK (Pedoman Standar Akuntansi dan Keuangan) No 31 mengenai akuntansi perbankan, bank adalah lembaga yang berperan sebagai perantara keuangan (financial intermediary) antara pihak-pihak yang kelebihan dana (surplus unit) dengan pihak-pihak yang memerlukan dana (defisit unit) serta sebagai lembaga yang berfungsi sebagai memperlancar lalu lintas pembayaran.

Sedangkan pengertian bank menurut Undang-Undang No 7 Tahun 1992 tentang perbankan sebagaimana telah diubah dengan Undang-Undang No 10 Tahun 1998 Pasal 1 mendefinisikan bank sebagai badan usaha yang menghimpun dana dari masyarakat dalam bentuk simpanan dan menyalurkannya kepada 
masyarakat dalam bentuk kredit dan atau bentuk-bentuk lainnya, dalam rangka meningkatkan taraf hidup masyarakat banyak.

Dari berbagai pengertian di atas dapat disimpulkan bahwa bank adalah suatu lembaga keuangan yang kegiatan utamanya menghimpun dana dan menyalurkannya dana kepada pihak-pihak yang membutuhkan dengan syarat-syarat tertentu. Bank sebagai lembaga intermediasi keuangan memberikan jasa-jasa keuangan baik kepada unit surplus maupun unit defisit. Menurut Kuncoro dan Suhardjono (2002:68), ada tiga fungsi utama bank dalam pembangunan ekonomi :

1. Bank sebagai lembaga yang menghimpun dana dari masyarakat.

2. Bank memiliki fungsi sebagai penyalur kredit.

3. Bank sebagai lembaga yang melancarkan transaksi perdagangan dan peredaran uang.

Kegiatan bank sehari-hari tidak lepas dari bidang keuangan. Secara sederhana kegiatan bank pada umumnya menghimpun dana dari masyarakat dan menyalurkannya dana (kredit) kepada masyarakat. Menurut Masyhud (2004: 85-86) ruang lingkup kegiatan usaha bank umum meliputi

1. Menghimpun dana dari masyarakat dalam bentuk simpanan berupa giro, deposito berjangka, sertifikat deposito dan atau bentuk lainnya yang dipersamakan dengan itu.

2. Memberikan kredit.

3. Menerbitkan surat pengakuan hutang.

4. Membeli, menjual atau menjamin atas resiko sendiri maupun untuk kepentingan dan atas perintah nasabahnya :

- Surat-surat wesel.

- Surat pengakuan hutang.

- Kertas perbendaharaan negara dan surat jaminan pemerintah.

- Sertifikat Bank Indonesia.

- Obligasi.

- Surat dagang berjangka waktu sampai dengan satu tahun.

- Surat berharga lain berjangka waktu sampai dengan satu tahun.

5. Memindahkan uang baik untuk kepentingan sendiri maupun untuk kepentingan nasabah.

6. Menempatkan dana pada, meminjam dana dari atau meminjamkan dana kepada bank lain, baik dengan menggunakan surat, sarana telekomunikasi maupun dengan wesel unjuk, cheque atau sarana lainnya.

7. Menerima pembayaran dari tagihan atas surat berharga dan melakukan perhitungan dengan atau antarpihak ketiga.

8. Menyediakan tempat untuk menyimpan barang dan surat berharga.

9. Melakukan kegiatan penitipan untuk kepentingan pihak lain berdasarkan suatu kontrak.

10.Melakukan penempatan dana dari nasabah kepada nasabah lainnya dalam bentuk surat berharga yang tidak tercatat di bursa efek.

11.Melakukan kegiatan anjak piutang, usaha kartu kredit dan kegiatan wali amanat.

12.Menyediakan pembiayaan dan atau melakukan kegiatan lain berdasarkan prinsip perbankan sesuai dengan ketentuan yang ditetapkan oleh Bank Indonesia.

13.Melakukan kegiatan lain yang lazim dilakukan oleh bank sepanjang tidak bertentangan dengan undangundang perbankan dan peraturan perundangan lainnya.

Selain melakukan kegiatan usaha sebagaimana disebut di atas, bank umum dapat pula melakukan halhal sebagai berikut :

1. Melakukan kegiatan dalam valuta asing dengan memenuhi ketentuan yang ditetapkan oleh Bank Indonesia.

2. Melakukan kegiatan penyertaan modal pada bank atau perusahaan lain di bidang keuangan, seperti sewa guna usaha (leasing), modal ventura, perusahaan efek, asuransi serta lembaga kliring penyelesaian dan penyimpanan dengan memenuhi ketentuan yang ditetapkan oleh Bank Indonesia.

3. Melakukan kegiatan penyertaan modal sementara untuk mengatasi akibat kegagalan kredit atau kegagalan pembiayaan berdasarkan prinsip syariah. Keduanya dengan syarat bank harus menarik kembali penyertaannya dalam jangka waktu tertentu dengan memenuhi ketentuan yang ditetapkan oleh Bank Indonesia.

4. Bertindak sebagai pendiri dana pension dan pengurus dana pension sesuai dengan ketentuan dalam perundang-undangan dana pension yang berlaku.

Untuk menilai suatu rasio kinerja keuangan bank digunakan lima aspek penilaian yaitu CAMEL yaitu Capital (Modal), Asset (Aktiva), Management (Manajemen), Earning (Rentabilitas), Liquidity (Likuiditas), dan Sensitivity To Market Risk (Sensitivitas Terhadap Resiko Pasar) yang telah ditetapkan dalam Surat Keputusan Direksi Bank Indonesia Nomor 30/12/KEP/DIR, Surat Edaran Bank Indonesia No. 30/3/UPPB tanggal 30 April 1997 dan Surat Edaran Bank Indonesia No.6/ 23./DPNP tanggal 31 Mei 2004 yaitu tentang 
Tata Cara Penilaian Tingkat Kesehatan Bank Umum (CAMEL Rating). Penilaian rasio kinerja keuangan dilakukan melalui analisis terhadap laporan keuangannya

\section{Rumusan Masalah}

Berdasarkan uraian serta penjelasan yang telah dikemukakan pada latar belakang dan identifikasi masalah, maka rumusan masalah penelitian ini adalah sebagai berikut :

1. Apakah secara simultan rasio kinerja keuangan mempengaruhi harga saham PT Bank Mandiri Tbk.

2. Apakah secara parsial rasio kinerja keuangan mempengaruhi harga saham PT Bank Mandiri Tbk.

\section{Tujuan Penelitian}

Adapun tujuan penelitian ini sebagai berikut:

1. Apakah secara simultan rasio kinerja keuangan mempengaruhi harga saham PT Bank Mandiri Tbk.

2. Apakah secara parsial rasio kinerja keuangan mempengaruhi harga saham PT Bank Mandiri Tbk.

\section{METODE PENELITIAN}

Penelitian yang digunakan adalah penelitian asosiatif merupakan penelitian yang bertujuan untuk mengetahui hubungan antara dua variabel atau lebih lainnya (Sugiyono,2011). Sesuai dengan definisi tersebut, maka penelitian asosiatif melakukan kajian hubungan, pengaruh atau bentuk lainnya antara satu variabel dengan variabel . Jenis data dalam penelitian ini adalah data kuantitatif dan sumber data yang digunakan dalam penelitian ini adalah data sekunder. Sedangkan teknik pengumpulan data dalam penelitian ini adalah studi pustaka yaitu yang berasal dari artikel atau jurnal dan studi dokumentasi yaitu Laporan Keuangan Tahunan yang diperoleh dari website www.bankmandiri.go.id periode 2014-2019.

\section{Identifikasi Variabel}

a. CAR untuk mengukur kemampuan bank dalam memenuhi kewajiban jangka panjangnya atau kemampuan bank untuk memenuhi kewajiban-kewajiban jika terjadi likuidasi.

b. NPM, menggambarkan kualitas manusianya dalam bekerja secara professional penerapan sistem manajemen resiko, dan kepatuhan bank terhadap ketentuan yang berlaku serta komitmen pada Otoritas Jasa Keuangan.

c. ROA digunakan untuk menghitung kemampuan bank dalam memperoleh keuntungan dari pengelolaan aktiva.

d. LDR merupakan ukuran terhadap kemampuan bank untuk memenuhi kemungkinan ditariknya deposit atau simpanan dari nasabah ataupun memenuhi kebutuhan masyarakat berupa kredit

e. Harga Saham merupakan harga per lembar saham pada periode penutupan bursa efek dikurangi dengan harga penutupan saham pada periode tahun sebelumnya .

\section{Klasifikasi Variabel}

a. Variabel bebas adalah CAR, NPL dan NPM., ROA dan LDR

b. Variabel terikat adalah Harga Saham

Definisi Operasional Variabel

Tabel 1. Rasio yang dianalisis meliputi aspek CAR, NPL dan NPM

\begin{tabular}{|l|l|l|l|l|}
\hline No & $\begin{array}{l}\text { Faktor Yang } \\
\text { Dinilai }\end{array}$ & \multicolumn{1}{|c|}{ Konsep } & \multicolumn{1}{c|}{ Indikator } & \multicolumn{1}{c|}{ Skala } \\
\hline 1 & Capital & $\begin{array}{l}\text { Mengukur kemampuan } \\
\text { bank dalam memenuhi } \\
\text { kewajiban jangka } \\
\text { panjangnya atau } \\
\text { kemampuan bank untuk } \\
\text { memenuhi kewajiban- } \\
\text { kewajiban jika terjadi } \\
\text { likuidasi. }\end{array}$ & $\begin{array}{l}\text { CAR (Capital } \\
\text { Adequacy Ratio). }\end{array}$ & $\begin{array}{l}\text { CAR= } \\
\text { Modal x 100 } \\
\text { Aktiva Tertimbang Menurut Resiko }\end{array}$ \\
\hline 2 & Manajemen & $\begin{array}{l}\text { Menggambarkan kualitas } \\
\text { manusianya dalam bekerja } \\
\text { secara professional }\end{array}$ & $\begin{array}{l}\text { NPM (Net Profit } \\
\text { Mangin), } \\
\text { Resiko }\end{array}$ & $\begin{array}{l}\text { NPM = } \\
\text { Laba Bersih x 100 } \\
\text { Pendapatan Operasional }\end{array}$ \\
\hline 3 & Equity & $\begin{array}{l}\text { Menghitung kemampuan } \\
\text { bank dalam memperoleh } \\
\text { keuntungan dari } \\
\text { pengelolaan aktiva. }\end{array}$ & $\begin{array}{l}\text { ROA (Return on } \\
\text { Assets) }\end{array}$ & $\begin{array}{l}\text { ROA = } \\
\text { Total Aktiva x 100\% } \\
\text { LLaba Sebelum Pajak }\end{array}$ \\
\hline
\end{tabular}




\begin{tabular}{|c|c|c|c|c|}
\hline \multicolumn{5}{|c|}{ Lanjutan } \\
\hline 4 & Liquidity & $\begin{array}{l}\text { Merupakan ukuran } \\
\text { terhadap kemampuan bank } \\
\text { untuk memenuhi } \\
\text { kemungkinan ditariknya } \\
\text { deposit atau simpanan dari } \\
\text { nasabah ataupun memenuhi } \\
\text { kebutuhan masyarakat } \\
\text { berupa kredit }\end{array}$ & $\begin{array}{l}\text { LDR (Loan } \\
\text { Deposit Ratio) }\end{array}$ & $\begin{array}{l}\text { LDR }= \\
\text { Dana Pihak Ketiga } \quad \text { x } 100 \% \\
\text { Jumlah Kredit Yang Diberikan }\end{array}$ \\
\hline 5 & Harga Saham & $\begin{array}{l}\text { Dihitung dengan cara } \\
\text { membandingkan harga } \\
\text { saham periode sekarang } \\
\text { pada akhir tahun dengan } \\
\text { harga saham periode } \\
\text { sebelumnya kemudian } \\
\text { dibagi dengan harga saham } \\
\text { pada periode sebelum }\end{array}$ & $\begin{array}{l}\text { Harga } \\
(H S)\end{array}$ & $\begin{array}{l}\text { Harga Saham } \\
\frac{\text { HS Tahun ini - HS Sebelumnya }}{\text { HS Sebelumnya }} \times 100 \%\end{array}$ \\
\hline
\end{tabular}

\section{Teknik dan Analisa Data}

\section{Pembentukan fungsi regresi.}

Hubungan antara Rasio Kinerja Keuangan ( Modal (CAR), Manajemen (NPM), Ekuitas (ROA), Likuiditas (LDR)) terhadap harga saham dinyatakan dalam suatu persamaan matematis. Alat analisis yang digunakan adalah regresi linear berganda, berikut persamaannya (Supranto,1995)

$$
\begin{array}{ll}
\mathrm{Y}=\mathrm{a}+\beta_{1} \mathrm{X}_{1}+\beta_{2} \mathrm{X}_{2+} \beta_{3} \mathrm{X}_{3}+\mathrm{e} \\
\text { Keterangan : } \\
\mathrm{Y} \quad=\text { Harga Saham } \\
\mathrm{a} \quad=\text { Konstanta. } \\
\beta_{1} \beta_{2} \beta_{3}=\text { Koefisien regresi } \\
\mathrm{X}_{1}=\text { CAR } \\
\mathrm{X}_{2}=\text { NPM } \\
\mathrm{X}_{3}=\text { ROA } \\
\mathrm{X}_{4} \quad=\text { LDR } \\
\mathrm{e} & =\text { Standar Error }
\end{array}
$$

\section{Analisis Regresi Linear Berganda.}

Analisis linear berganda adalah analisis yang digunakan untuk mengetahui arah dan besarnya pengaruh Rasio Kinerja Keuangan (CAR, NPM, ROA dan LDR) terhadap Harga Saham. Dalam penelitian ini metode analisis data yang digunakan adalah Regresi Linear Berganda (Multiply Linear Regression Method)

\section{Uji Hipotesis.}

Berdasarkan pada latar belakang masalah, perumusan masalah, tujuan penelitian serta telaah pustaka seperti yang telah diuraikan tersebut di atas, maka hipotesis yang diajukan dalam penelitian ini adalah :

1. H1 = Terdapat pengaruh secara simultan antara rasio kinerja keuangan terhadap harga saham PT Bank Mandiri Tbk.

2. H2. = Terdapat pengaruh secara parsial antara rasio kinerja keuangan terhadap harga saham PT Bank Mandiri, Tbk.

Pengujian hipotesis penelitian dilakukan dengan ui parsial (uji-T) dan uji simultan (Uji-F) serta uji koefisien standardized. 


\section{HASIL DAN PEMBAHASAN}

\section{Pembentukan Fungsi Regresi}

\begin{tabular}{|c|c|c|c|c|c|c|}
\hline \multicolumn{7}{|c|}{ efficier } \\
\hline \multirow[b]{2}{*}{ Model } & & \multicolumn{2}{|c|}{ Unstandardized Coefficients } & \multirow{2}{*}{$\begin{array}{l}\text { Standardized } \\
\text { Coefficients } \\
\text { Beta }\end{array}$} & \multirow[b]{2}{*}{$\mathrm{t}$} & \multirow[b]{2}{*}{ Sig. } \\
\hline & & B & Std. Error & & & \\
\hline \multirow[t]{5}{*}{1} & (Constant) & -4.454 & 15.031 & & -.296 & .817 \\
\hline & CAR & 3.304 & .813 & .428 & 4.065 & .154 \\
\hline & NPM & 2.712 & .141 & 1.774 & 19.279 & .033 \\
\hline & ROA & 49.212 & 4.381 & 1.490 & 11.233 & .057 \\
\hline & LDR & -3.224 & .299 & -.977 & -10.772 & .059 \\
\hline
\end{tabular}

a. Dependent Variable: HARGA SAHAM

Hasil pengolahan SPSS dapat ditunjukkan melalui persamaan regresi linier berganda sebagai berikut:

$$
\mathrm{Y}=-4,454+3,304 \mathrm{X}_{1}+2,712 \mathrm{X}_{2}+49,212 \mathrm{X}_{3}-3,224 \mathrm{X}_{4}+\mathrm{e}
$$

Berdasarkan model regresi linier berganda diatas dapat dilihat bahwa nilai konstanta (a) adalah -4,454. Hal ini berarti bahwa apabila nilai variabel bebas yang terdiri dari variabel CAR, NPM, ROA dan LDR sama dengan nol, maka besarnya variabel terikat (harga saham) adalah $-4,454$. Besarnya koefisien regresi variabel CAR $\left(b_{1}\right)$ adalah 3,304 dan memiliki pengaruh yang positif terhadap harga saham. Hal ini berarti jika terjadi setiap peningkatan pada variabel bebas yaitu CAR akan menaikkan variabel harga saham sebesar 3,304 dengan asumsi variabel bebas lainnya adalah tetap. Besarnya koefisien regresi variabel NPM $\left(b_{2}\right)$ adalah 2,712 dan memiliki pengaruh yang positif terhadap harga saham. Hal ini berarti jika terjadi setiap peningkatan pada variabel NPM akan meningkatkan variabel harga saham 2,712 dengan asumsi variabel bebas lainnya adalah tetap.

Besarnya koefisien regresi variabel ROA $\left(b_{3}\right)$ adalah 49,212 dan memiliki pengaruh yang positif terhadap harga saham. Hal ini berarti jika terjadi setiap peningkatan pada variabel ROA akan meningkatkan variabel harga saham sebesar 49,212 dengan asumsi variabel bebas lainnya adalah tetap. Besarnya koefisien regresi variabel LDR $\left(b_{4}\right)$ adalah $-3,224$ dan memiliki pengaruh yang negatif terhadap harga saham. Hal ini berarti jika terjadi setiap penurunan pada variabel LDR akan meningkatkan harga saham sebesar 2,712 dengan asumsi variabel bebas lainnya adalah tetap.

Dari persamaan regresi linier berganda tersebut dapat dilihat bahwa bagaimana pengaruh dari variabel bebas (CAR, NPM, ROA dan LDR terhadap variabel terikat (harga saham). Pengaruh yang positif menunjukkan bahwa perubahan variabel bebas searah dengan perubahan variabel terikat. Pengaruh yang negative menunjukkan bahwa perubahan variabel bebas tidak searah dengan perubahan variabel terikat.

\section{Uji Asumsi Klasik}

- Uji Normalitas

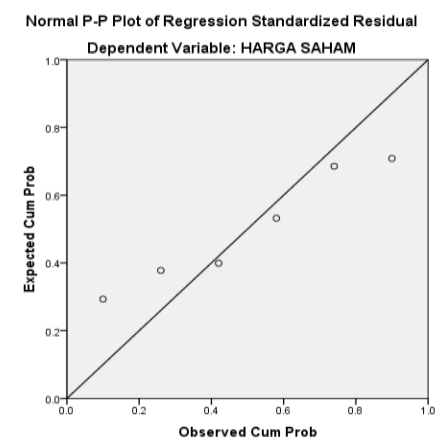

Berdasarkan tabel di atas menunjukkan pola distribusi yang mendekati normal. Karena data berdistribusi normal dapat ditentukan berdasarkan bentuk gambar kurva yang kemiringan cenderung seimbang antara sisi kanan dan kiri. 
- Uji Heterokedastisitas

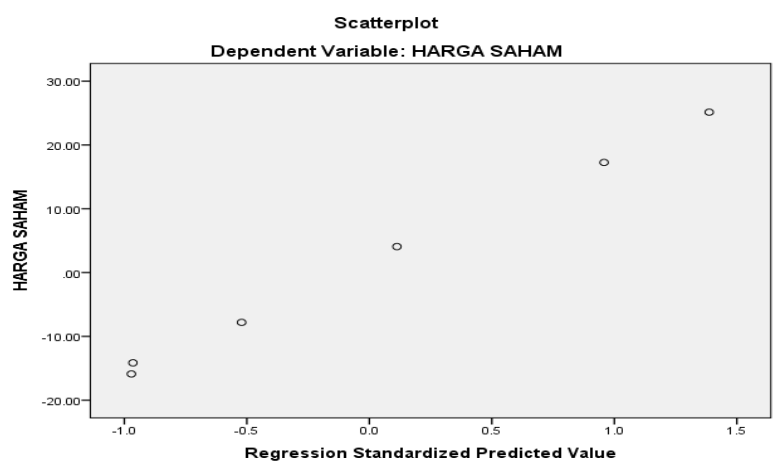

Hasil uji heterokedastisitas menunjukkan bahwa sebaran titik acak baik di atas maupun di bawah angka 0 dari sumbu Y. Dapat disimpulkan tidak erjadi heterokedastisitas dalam model regresi ini.

- Uji Autokorelasi

Tabel 3. Model Summary ${ }^{\mathrm{b}}$

\begin{tabular}{ll|l|l|l|l} 
Model & $\mathrm{R}$ & R Square & $\begin{array}{l}\text { Adjusted } \\
\text { Square }\end{array}$ & $\begin{array}{l}\text { Std. Error of the } \\
\text { Estimate }\end{array}$ & Durbin-Watson \\
\hline 1 & $.999^{\mathrm{a}}$ & .998 & .992 & 1.49066 & 1.979 \\
\hline $\begin{array}{l}\text { a. Predictors: (Constant), LDR, NPM, CAR, ROA } \\
\text { b. Dependent Variable: HARGA SAHAM }\end{array}$
\end{tabular}

Dari hasil ouput didapatkan nilai statistic uji Durbin Watson sebesar 1.979 (mendekati 2). Dengan demikian dapat disimpulkan bahwa tidak terdapat autokorelasi antara variabel bebas (CAR, NPM, ROA dan LDR) terhadap harga saham.

\section{Uji Hipotesis}

- Uji T

Tabel 4. Coefficients ${ }^{\mathrm{a}}$

\begin{tabular}{|c|c|c|c|c|c|c|}
\hline \multirow[b]{2}{*}{ Model } & & \multicolumn{2}{|c|}{ Unstandardized Coefficients } & \multirow{2}{*}{$\begin{array}{l}\text { Standardized } \\
\text { Coefficients } \\
\text { Beta }\end{array}$} & \multirow[b]{2}{*}{$\mathrm{t}$} & \multirow[b]{2}{*}{ Sig. } \\
\hline & & $\mathrm{B}$ & Std. Error & & & \\
\hline 1 & (Constant) & -4.454 & 15.031 & & -.296 & .817 \\
\hline & CAR & 3.304 & .813 & .428 & 4.065 & .154 \\
\hline & NPM & 2.712 & .141 & 1.774 & 19.279 & .033 \\
\hline & ROA & 49.212 & 4.381 & 1.490 & 11.233 & .057 \\
\hline & LDR & -3.224 & .299 & -.977 & -10.772 & .059 \\
\hline
\end{tabular}

a. Dependent Variable: HARGA SAHAM

Berdasarkan tabet output di atas diketahui signifikasi (sig) variabel CAR $\left(\mathrm{X}_{1}\right)=0,154$, variabel NPM $\left(X_{2}\right)=0,33$, variabel ROA $\left(X_{3}\right)=0,57$ dan variabel LDR $\left(X_{4}\right)=0,59$. Apabila nilai signifikansi $>0.05$, maka dapat disimpulkan tidak ada pengaruh CAR, ROA dan LDR terhadap harga saham. Sedangkan siginifkansi NPM $\left(\mathrm{X}_{2}\right)=0,033$ lebih kecil dari probabilitas 0,05 maka terdapat pengaruh yang siginifikan terhadap harga saham dan pengaruh paling dominan dibandingkan variabel bebas lainnya (CAR, ROA dan $\mathrm{LDR})=19,279$

- Uji F

Tabel 5. ANOVA ${ }^{a}$

\begin{tabular}{lll|l|l|l|l} 
Model & & Sum of Squares & df & Mean Square & F & Sig. \\
\hline \multirow{2}{*}{1} & Regression & 1445.597 & 4 & 361.399 & 162.640 & $.059^{\mathrm{b}}$ \\
\cline { 2 - 8 } & Residual & 2.222 & 1 & 2.222 & & \\
\cline { 2 - 8 } & Total & 1447.819 & 5 & & & \\
\hline
\end{tabular}

a. Dependent Variable: HARGA SAHAM

b. Predictors: (Constant), LDR, NPM, CAR, ROA

Berdasarkan tabet output di atas diketahui signifikasi (sig) 0,59. Apabila nilai signifikansi > 0.05, maka dapat disimpulkan tidak ada pengaruh CAR, NPM, ROA dan LDR terhadap harga saham. 
- Koefisien determinasi.

Tabel 6. Model Summary ${ }^{b}$

\begin{tabular}{|c|c|c|c|c|c|}
\hline Model & $\mathrm{R}$ & R Square & $\begin{array}{ll}\text { Adjusted } & R \\
\text { Square } & \\
\end{array}$ & $\begin{array}{l}\text { Std. Error of the } \\
\text { Estimate }\end{array}$ & Durbin-Watson \\
\hline 1 & $.999^{\mathrm{a}}$ & .998 & .992 & 1.49066 & 1.979 \\
\hline
\end{tabular}

Berdasarkan tabel diatas dapat dilihat bahwa hasil analisis menunjukkan nilai koefisen determinasi (R) sebesar 0,998 (99,80 \%). Hal ini berarti kemampuan variabel independen yang terdiri dari CAR, NPM, LDR dan ROA dalam menjelaskan variasi variabel dependen masih dibilang cukup kuat karena melebihi atau diatas $50 \%$ yaitu $99,80 \%$. Selanjutnya sisa dari nilai R yaitu sebesar $0.02(2 \%)$ adalah merupakan pengaruh dari variabel lain yang tidak dimasukkan ke dalam penelitian ini.

\section{PENUTUP}

\section{Simpulan}

Berdasarkan hasil penelitian yang sudah dipaparkan, maka diperoleh kesimpulan sebagai berikut:

1. Berdasarkan hasil analisis data di atas dapat disimpulkan bahwa variabel CAR, ROA dan LDR tidak berpengaruh secara signifikan terhadap harga saham. Hanya variabel bebas NPM yang memiliki pengaruh yang paling besar dan sangat signifikan

2. Sedangkan berdasarkan hasil uji simultan menunjukkan bahwa secara bersama-sama variabel (CAR, NPM, LDR dan ROA) tidak berpengaruh secara siginifikan terhadap harga saham.

3. Nilai adjusted R square sebesar 99,80\% menunjukkan bahwa nilai variansi variabel independen sebesar $99,80 \%$. Sedangkan $2 \%$ dipengaruhi faktor lain.

4.

\section{Saran}

Saran yang dapat diberikan yaitu

1. Bagi perbankan yang merupakan emiten di Bursa Efek Indonesia untuk meningkatkan harga saham hendaknya dilakukan dengan peningkatan pendapatan operasional dan efisiensi biaya. Hal ini akan menyebabkan peningkatan atas laba perusahaan. Laba yang tinggi akan memberikan deviden yang besar bagi pemegang saham. Investor cenderung untuk membeli saham yang mampu memberikan return berupa deviden dan capital gain yang tinggi.

2. Untuk peneliti selanjutnya hendaknya perlu menambahkan jangka waktu ataupun variabel lainnya yang mempengaruhi harga saham.

\section{DAFTAR PUSTAKA}

Dendawijaya, Lukman. (2009). Manajemen Perbankan, Edisi Kedua. Jakarta: Ghalia Indonesia. Dyah, Kumala T. (2017). Pengaruh Kinerja Keuangan Terhadap Return Saham.

Joko, Sulistyo. (2010). SPSS Multivariate. Bhuana Ilmu Populer

Kuncoro, Mudrajad dan Suhardjono. (2002). Bank dan Lembaga Keuangan Lainnya. Yogyakarta: STIE YKPN.

Masyhud, Ali. ((2004). Aset Liability Management Menyiasati Risiko Pasar dan Risiko Operasional Dalam Perbankan . Jakarta: Gramedia Jakarta.

Sudirman, I Ketut. (2000). Manajemen Perbankan Suatu Aplikasi Dasar. Denpasar: T BP.

Sumantoro. (1990). Pengantar Pasar Modal di Indonesia, Edisi Pertama. Jakarta: Ghalia Indonesia.

Sutojo Siswanto. (1997). Manajemen Terapan Bank. Jakarta: PT Pustaka Binaman Presindo

www.bankmandiri.co.id

www.ojk.go.id, Laporan Bank Umum 